DOI: $10.21802 / \mathrm{artm} .2021 .1 .17 .80$.

UDC 616.379-008.64

\title{
USE OF ERYTHROCYTIC CONTAINERS FOR DELIVERY OF MEDICINES TO THE INFLAMMATION SITE
}

\author{
I.K. Churpiy, N.R. Golod, O.V. Yaniv, L.P. Fedorivska, M.V. Fitsych, A.P. Macogin
}

Ivano-Frankivsk National Medical University, Department of Physical Rehabilitation, Ergotherapy with a course of physical education, Ivano-Frankivsk City, Ukraine,

ORCID ID: 0000-0003-1735-9418, e-mail: ch.igor.if@gmail.com,

ORCID ID: 0000-0003-0996-6920, e-mail:n.golod@ukr.net,

ORCID ID: 0000-0003-0921-3304,e-mail: olesiayaniv333@gmail.com,

ORCID ID: 0000-0002-3911-0106, e-mail:lesiafedorivska@gmail.com,

ORCID ID:0000-0002-6579-699X, e-mail: marianafitsych@ukr.net,

ORCID ID:0000-0002-2928-2748, e-mail: makogin1995@ukr.net

Abstract. In recent decades, scientists have been attracted by the idea of developing methods for targeted transport of drugs and diagnostic drugs directly into the area of inflammation.

Experimental and single clinical studies have revealed high efficiency and prospects for targeted delivery of various drugs. Most known carriers have a number of disadvantages, both in the range and amount of drugs they can bind, and in their ability to prevent contact of transport drugs with healthy tissues. In addition, there are difficulties associated with the toxicity and immunogenicity of carriers, their availability, cost, complexity of preparation. Transport systems that use the body's own cells are the most advantageous in terms of biocompatibility. Among them, erythrocytes, platelets and leukocytes are used as vehicles.

Currently, the most promising in terms of drug transport is the use of erythrocyte containers.

Pharmacokinetic studies have shown that with this route of administration, the concentration of antibiotic in the bile in patients with inflammatory diseases of the biliary tract, 4.7 times higher than with other routes of administration, and their therapeutic activity is maintained for a much longer time. When the erythrocyte containers were applied topically, the antibiotic concentration in the wound and surrounding tissue was 10 times higher than that achieved by traditional soft tissue puncture.

In order to prove the ability of erythrocyte containers to capture drugs and concentrate in the inflammatory focus in 10 patients with this pathology at the beginning of treatment was injected into the femoral artery $1 \%-1 \mathrm{ml}$ of nicotinic acid in $0.9 \%-2 \mathrm{ml}$ of saline, and the following day the same patient in the same dose it was administered in erythrocyte containers. The time of onset of the reaction and the duration of the drug were determined, taking into account subjective and objective data.

The ability of erythrocyte containers to seize drugs is evidenced by the results obtained by us: with the introduction of nicotinic acid in its pure form, the reaction occurred after $115411 \pm 0,041$ and lasted $715211 \pm 0,0311$. Objectively, there was a gradual reddening of the face and mild hyperemia. With the introduction of erythrocyte containers with nicotinic acid, the reaction occurred through $214311 \pm 0,0311$ and lasted $1112411 \pm 0,0211$.

Subjectively, patients were characterized by a milder course of the reaction.

The development of granulation tissue in the wound with the introduction of erythrocyte containers with antibiotics began on day 8-9, and the marginal epithelialization - on day 10-12. In the control group, the appearance of granulation tissue and epithelialization in the wound were on 12-13 and 14-15 days, respectively.

Keywords: erythrocyte containers, diabetes mellitus, diabetic angiopathy.

Introduction. In recent decades, the attention of scientists has been drawn to the idea of developing methods of targeted transport of drugs and diagnostic drugs directly into the area of inflammation [3]. It opens wide opportunities not only in drug therapy of various diseases, but also in their topical diagnosis [2]. This problem deserves special scientific and practical interest in connection with the reduction of side effects of drugs: toxic effects of large doses of the drug, allergies, the emergence of resistant strains of microorganisms, suppression of immunity [3].

Side effects of drugs, their low effectiveness is due to low bioavailability, high therapeutic dose and concentration of drugs not in the area of damage, but in the serum in almost uniform concentrations in all organs. To achieve this goal, fixed drugs are used: "bioactive capsules" with the use of artificial membranes; liposomes, capsules of human albumin, magnetic microspheres and microcapsules of nylon $[2,3,4]$.

Experimental and single clinical studies have revealed high efficiency and prospects for targeted delivery of various drugs to the body. Most known carriers have a number of disadvantages, both in the range and amount of drugs they can bind, and in their ability to prevent contact of transport drugs with healthy tissues. In addition, there are difficulties associated with the toxicity 
and immunogenicity of carriers, their availability, cost, complexity of preparation. Transport systems that use the body's own cells are the most advantageous in terms of biocompatibility. Among them, erythrocytes, thrombocytes and leukocytes are used as vehicles [4].

It should be noted that the withdrawal from the bloodstream of drugs that are included in the uniform elements of the blood by conventional transport mechanisms can be prolonged from several hours to several days. Which contributes to the effectiveness of therapeutic treatment [1].

Currently, the most promising in terms of drug transport is the use of erythrocyte containers. For the first time erythrocytes-carriers were used in cardiac practice of G.P. Samokhin, M.D. Smirnov ect., (1986) for the treatment of damaged areas of the vascular system. An antibiotic or other drug substances and an antibody to type I, II, or III collagen were deposited on the erythrocyte carrier, which caused a specific delivery of erythrocyte shadows to the area of endothelial exfoliation and the release of collagen into the lumen of the vessel. It has been proven that such erythrocytes continue to circulate in the blood for a long time (half-life is several days).

J.Sh. Zhumadilov, R.V. Makarenkova (1990) studied the stability of antibiotics with autologous erythrocyte shadow carriers in the bloodstream, and their use in the treatment of purulent-necrotic lesions of the liver and biliary tract. To do this, dogs in the laboratory were caused to have destructive cholecystitis. The control group of dogs was injected intravenously with a solution of kanamycin once a day. In the main group, kanamycin, concentrated in autologous containers, was administered intravenously at the same dose. The treatment lasted 5 days. A comparative analysis of the traditional prenatal administration of antibiotics and its targeted transport in erythrocyte shadows revealed the high efficiency of the latter. Thus, in the main group of animals after two days of treatment the normalization of body temperature was observed, dogs became more active. Control animals remained lethargic and feverish. Pharmacokinetic studies have revealed significant differences in the concentration of kanamycin in liver tissue depending on the method of administration [4].

In 1991, a group of physicians [2, 4] used erythrocyte containers saturated with antibiotics in a clinical setting in patients with acute cholecystitis. They concluded that the use of targeted antibiotic transport in autologous erythrocyte shadows can adequately stabilize clinical and laboratory manifestations of acute cholecystitis, prevent the development of infectious complications, 4.5 times reduce the length of hospital stay, and optimize planned surgical treatment.

E.V. Medvetskiy, M.E. Nichitaylo and etc. (1998) improved the method of manufacturing erythrocyte containers because Zh. Sh. Zhumadil's method was cumbersome and unsuitable for widespread use in clinical practice for the treatment of patients with pathology of the hepatobiliary system [7].

Pharmacokinetic studies have shown that with this route of administration, the concentration of antibiotic in the bile in patients with inflammatory diseases of the biliary tract, 4.7 times higher than with other routes of administration, and their therapeutic activity is maintained for a much longer time. When the erythrocyte containers were applied topically, the antibiotic concentration in the wound and surrounding tissue was 10 times higher than that achieved by traditional soft tissue puncture.

It should be noted the low concentration of antibiotic in the serum, which reduced the toxicity of the drug. Analysis of the results of using this method in clinical practice showed that the frequency of purulent complications in biliary tract surgery decreased by 2.5 times, in liver surgery - 4 times. The duration of treatment of soft tissue abscesses was reduced by 3.5 times. The use of the method also significantly reduced the consumption of antibiotics, which is of economic importance.

The aim of the study: to analyze the use of biological carriers as a means of drug delivery to the area of inflammation.

We used erythrocyte containers for the treatment of purulent-necrotic processes in diabetic angiopathy of the lower extremities is a complex and long-term process [6], which involves the use of a large number of drugs that act on different links in the pathogenesis of this disease. This raises an equally important question about the route of administration of drugs in order to maximize the therapeutic effect. Of the existing methods of drug administration, in this surgical pathology, a number of authors consider the most appropriate pre-arterial [2], which contributes to the rapid and local impact on the pathological process.

Materials and methods. 55 patients with diabetic angiopathy of the lower extremities of grade III and IV were examined. The age of patients ranged from 40 to 70 years and older. The duration of the disease is from 3 to 20 years and more. All patients underwent a course of prearterial administration of an antibiotic concentrated in erythrocyte containers by puncture of the femoral artery on the background of basic treatment, which included diet therapy, insulin therapy, improvement of microcirculation and rheological properties of blood, antibacterial and symptomatic therapy. If necessary, "economical" surgical interventions on the foot were performed (opening of abscesses, necrectomy, amputation of fingers, metatarsals, longitudinal and transverse half amputation of the foot).

In order to prove the ability of erythrocyte containers to capture drugs and concentrate in the inflammatory focus in 10 patients with this pathology at the beginning of treatment was injected into the femoral artery $1 \%-1 \mathrm{ml}$ of nicotinic acid in $0.9 \%-2 \mathrm{ml}$ of saline, and the following day the same patient in the same dose it was administered in erythrocyte containers. The time of onset of the reaction and the duration of the drug were determined, taking into account subjective and objective data. Subsequently, in 45 patients with this pathology, erythrocyte containers were saturated with an antibiotic, which was selected according to the antibioticogram. Control of drug delivery to the site of inflammation was performed on cytological impressions of the wound surface. Material collection was performed in 12 patients with diabetic angiopathy complicated by purulent-necrotic processes of the lower extremities. Smears were taken from the wound after $0.5 ; 1.5 ; 3 ; 4 ; 6 ; 12 ; 24 ; 36$ hours after administration, dried and fixed with $96^{\circ}$ ethyl alcohol. Romanovsky-Gimza smears were painted. Phosphate buffer ( $\mathrm{pH} \mathrm{6.5)}$ was used instead of water to 
dilute the paint to make high-quality cytological impressions. The working paint solution was prepared at the rate of 1 volume of paint per 8 volumes of buffer. The fixed cytological object was treated with the highest possible layer of paint. The staining exposure was 30-45 minutes.

Research results and their discussion. The ability of erythrocyte containers to seize drugs is evidenced by the results obtained by us: with the introduction of nicotinic acid in its pure form, the reaction occurred after $1^{1} 54^{11} \pm 0,04^{11}$ and lasted $7^{1} 52^{11} \pm 0,03^{11}$. Objectively, there was a gradual reddening of the face and mild hyperemia. With the introduction of erythrocyte containers with nicotinic acid, the reaction occurred through $2^{1} 43^{11} \pm 0,03^{11}$ and lasted $11^{1} 24^{11} \pm 0,02^{11}$.

Objectively, there was a gradual reddening of the face and mild hyperemia. Subjectively, patients were characterized by a milder course of the reaction. Microscopic examination of erythrocyte containers phagocytosed by neutrophils was detected in smearsimprints from the wound.

Studies have shown that leukocyte-phagocytosed cell shadows were detected in the wound contents in all examined patients. In the wound area, the number of neutrophils with phagocytosed erythrocyte containers dynamically increased from $30 \mathrm{~min}$ to 12 hours after their pre-arterial administration to the patient. Subsequently, the number of such neutrophils gradually decreased and after 36 hours in the field of view, single phagocytosed erythrocyte containers were observed.

The development of granulation tissue in the wound with the introduction of erythrocyte containers with antibiotics began on day 8-9, and the marginal epithelialization on day 10-12. In the control group, the appearance of granulation tissue and epithelialization in the wound were on days 12-13 and 14-15, respectively.

\section{Conclusions:}

1. The use of autologous storage containers for the treatment of patients with various surgical pathologies is a modern, highly effective method.

2. Erythrocyte containers have the ability to concentrate drugs and thus create a targeted prolonged action of the drug and its maximum long-term therapeutic effect.

3. Drugs concentrated in erythrocyte containers do not cause adverse reactions in the body and can be recommended for widespread use in practical medicine.

4. Detection of erythrocyte containers during microscopic examination in cytological prints from the wound indicates their penetration outside the vessels into the interstitial tissue in the area of purulent-necrotic process, where they are released from the drug. In addition, a high concentration of the latter and its prolonged action in the site of inflammation for 36 hours.

\section{References:}

1. Zaremba VS, Fedchyshyn NR, Bokhonko RL, Herych HI. Deiaki aspekty diahnostyky ta likuvannia diabetychnoi stopy. Shpytalna khirurhiia. 2019; 4:6366.

2. Henynh TP, Kolker YY, Zhumadylov ZhSh. Yspolzovanye formennykh elementov krovy dlia napravlennoi dostavky khymyoterapevtycheskykh y dyahnostycheskykh preparatov $\mathrm{v}$ ochah porazhenyia. Antybyotyky y khymyoterapyia. 1988; 11:867-871.

3. Churpiy IK, Honchar MH, Dub OI. Vykorystannia vlasnykh klityn orhanizmu dlia transportu likarskykh zasobiv (ohliad). Klinichna khirurhiia. 2001; 4(698):52-54.

4. Zhumadylov ZhSh, Makarenkova RV. Farmakokynetyka pry napravlennom transporte $\mathrm{v}$ pechen $\mathrm{V}$ teniakh erytrotsytov $\mathrm{u}$ zhyvotnykh s eksperymentalnym ostrym kholetsystytom. Antybyotyky y khymyoterapyia. 1990; 11(35):37-38.

5. Churpiy IK, Honchar $\mathrm{MH}$. Viddaleni rezultaty likuvannia khvorykh $\mathrm{z}$ diabetychnoiu stopoiu $\mathrm{Z}$ vykorystanniam erytrotsytarnykh konteineriv. Klinichna khirurhiia. 2004; 3:75-77.

6. Zaremba VS, Zimenkovskyi AB, Kuzin IA, Tydash IH. Kompleksne likuvannia hniino-nekrotychnykh urazhen nyzhnikh kintsivok u khvorykh na tsukrovyi diabet. Praktychna medytsyna. 1999; 1-2:40-42.

7. Nychytailo MIu, Medvetskyi EB, Hyndrych LO, Skuns AV, Ohorodnyk PV. Spriamovanyi transport antybiotykiv pry hniino-zapalnykh zakhvoriuvanniakh pechinky ta zhovchnykh shliakhiv. Shpytalna khirurhiia. 1999; 2:43-46.

\section{УДК 616.379-008.64 \\ ИСПОЛЬЗОВАНИЕ ЭРИТРОЦИТАРНЫХ КОНТЕЙНЕРОВ ДЛЯ ДОСТАВКИ ЛЕКАРСТВЕННЫХ ПРЕПАРАТОВ В ОЧАГ ВОСПАЛЕНИЯ}

И.К. Чурпий, Н.Р. Голод, А.В. Янив, Л.П. Федоровськая, М.В. Фицич, А.П. Макогин

Ивано-Франковский нацииональный медицинский университет, кафедра физической реабилитации, эрготерапии с курсом физического воспитания, 2. Ивано-Франковск, Украина, ORCID ID: 0000-0003-1735-9418, e-mail: ch.igor.if@gmail.com, ORCID ID: 0000-0003-0996-6920, e-mail:n.golod@ukr.net, ORCID ID: 0000-0003-0921-3304, e-mail: olesiayaniv333@gmail.com, ORCID ID: 0000-0002-3911-0106, e-mail: lesiafedorivska@gmail.com, ORCID ID: 0000-0002-6579-699X, e-mail: marianafitsych@ukr.net, ORCID ID: 0000-0002-2928-2748, e-mail:makogin1995@ukr.net

Резюме. В статье доказана и обоснована целесообразность и эффективность доартериального введения лекарственных препаратов, сосредоточенных в эритроцитарных контейнерах при лечении диабетических ангиопатий нижних конечностей, осложненных гнойно-некротическими процессами.

Последние десятилетия внимание ученых привлекает идея разработки методов целенаправленного транспорта лекарственных и диагностических препаратов непосредственно в зону воспаления. 
В настоящее время наиболее перспективным в плане транспорта медикаментозных препаратов является применение эритроцитарных контейнеров.

Системы транспорта, в которых используются собственные клетки организма, наиболее выгодные с точки зрения биологической совместимости. Среди них в качестве транспортных средств используют эритроциты, тромбоциты и лейкоциты.

При местном применении эритроцитарных контейнеров концентрация антибиотика в ране и окружающей ткани была в 10 раз выше аналогичной, которая достигается традиционным обкалыванием мягких тканей.

Использование метода позволило также существенно сократить расход антибиотика, что имеет экономическое значение.

Для того, чтобы доказать способность эритроцитарных контейнеров захватывать лекарственные препараты и концентрироваться в очаге воспаления, 10 больным с данной патологией в начале лечения вводили в бедренную артерию 1\%-1 мл р-н никотиновой кислоты на 0.9\%-2 мл физиологическом растворе, а на следующий день тем самым больным в той же дозе ее вводили в эритроцитарных контейнерах.

Развитие грануляционной ткани в ране при введении эритроцитарных контейнеров с антибиотиком начиналос на 8-9 сутки, а краевой эпителизации на 10-12 день. В контрольной группе появление грануляционной ткани и эпителизации в ране соответственно были на 12-13 и 14-15 сутки.

Ключевые слова: эритроцитарные контейнеры, сахарный диабет, диабетическая ангиопатия.

\section{УДК 616.379-008.64 \\ ВИКОРИСТАННЯ ЕРИТРОЦИТАРНИХ КОНТЕЙНЕРІВ ДЛЯ ДОСТАВКИ ЛКАРСЬКИХ ПРЕПАРАТІВ У ВОГНИШЩЕ ЗАПАЛЕННЯ}

\author{
І.К. Чурпій, Н.Р. Голод, О.В. Янів, \\ Л.П. Федорівська, М.В. Фіцич, А.П. Макогін
}

Івано-Франківський національний медичний університет, кафедра фізичної реабілітаиії, ерготерапії з курсом фізичного виховання,

м. Івано-Франківськ, Украӥна,

ORCID ID: 0000-0003-1735-9418,

e-mail: ch.igor.if@gmail.com,

ORCID ID: 0000-0003-0996-6920,

e-mail:n.golod@ukr.net,

ORCID ID: 0000-0003-0921-3304, e-mail: olesiayaniv333@gmail.com, ORCID ID: 0000-0002-3911-0106,

e-mail:lesiafedorivska@gmail.com, ORCID ID: 0000-0002-6579-699X, e-mail: marianafitsych@ukr.net, ORCID ID: 0000-0002-2928-2748, e-mail:makogin1995@ukr.net

Резюме. В статті доведено і обгрунтовано доцільність і ефективність доартеріального введення лікарських препаратів, зосереджених в еритроцитарних контейнерах, при лікуванні діабетичних ангіопатій нижніх кінцівок, ускладнених гнійно-некротичними процесами.

Останні десятиріччя увагу науковців привертає ідея розробки методів цілеспрямованого транспорту лікарських і діагностичних препаратів безпосередньо в зону запалення

На сьогодні найбільш перспективним способом транспорту медикаментозних препаратів $\epsilon$ застосування еритроцитарних контейнерів.

Системи транспорту, в яких використовуються власні клітини організму, найбільш вигідні 3 точки зору біологічної сумісності. Серед них в якості транспортних засобів використовують еритроцити, тромбоцити і лейкоцити

При місцевому застосуванні еритроцитарних контейнерів концентрація антибіотика в рані і навколишній тканині була в 10 разів вища від аналогічної, яка досягається традиційним обколюванням м'яких тканин.

Використання методу дозволило також суттєво скоротити розхід антибіотика, що має економічне значення.

Для того, щоб довести здатність еритроцитарних контейнерів захоплювати лікарські препарати та концентруватись у вогнищі запалення, 10 хворим із цією патологією на початку лікування вводили в стегнову артерію 1\%-1мл р-н нікотинової кислоти на 0.9\%2 мл фізіологічному розчині, а наступного дня тим самим хворим у тій самій дозі їі вводили в еритроцитарних контейнерах.

Розвиток грануляційної тканини в рані при введенні еритроцитарних контейнерів 3 антибіотиком починався на 8-9 добу, а краєвої епітелізації - на 10-12 день. У контрольній групі поява грануляційної тканини і епітелізації в рані відповідно були на 12-13 і 1415 добу.

Ключові слова: еритроцитарні контейнери, цукровий діабет, діабетична ангіопатія.

Стаття надійшла в редакцію 10.03. 2021 р. 